\title{
Ocular effects of chlorpromazine and oxypertine on beagle dogs
}

\author{
J. LEGROS, I. ROSNER, AND G. BERGER \\ Centre de Recherche Winthrop, 2 I-Dijon D, France
}

Ocular abnormalities induced by phenothiazine medication have been reported in man (Goar and Fletcher, 1957; Grutzner, 1969; Leinefelder and Burian, 1964; Siddall, 1965; Verrey, 1956) and reproduced experimentally in animals (Cerletti and Meier-Ruge, 1968; McDonald, Snell and Lerner, 1967; Reinert, and Rutty, 1969; Smith, Gavitt, and Karmin, 1966; Wagner, 1956; Weinstock and Scott, 1967). Only a few of the papers published have dealt with electrophysiological changes in visual function (Boet, 1969; Franceschetti, François, and Babel, I964; Henkes, 1967). In our experiments, we have tried to detect chlorpromazine-induced ocular changes in the dog and to follow their course after stopping the medication. The changes were compared with those possibly induced by oxypertine, a neuroleptic of a different chemical type. Before, during, and after medication we studied the eyes by means of the slit lamp, the ophthalmoscope, electroretinography, histopathology, and biochemical estimations.

\section{Materials and methods}

The study was carried out on 24 beagle dogs divided into three groups made up of an equal number of males and females:

(I) eight unmedicated control dogs;

(2) eight dogs treated orally with chlorpromazine for $4 \mathrm{mths}$, the dosage being progressively increased over $6 \mathrm{wks}$ from 5 to $30 \mathrm{mg}$./kg./day;

(3) eight dogs treated orally with oxypertine for $4 \mathrm{mths}$, the dosage being progressively increased over 6 wks from 2.5 to $15 \mathrm{mg}$. $/ \mathrm{kg}$./day.

Doses are expressed in terms of base. The animals were medicated 6 days a week by means of an oesophageal probe.

Before beginning medication, all the dogs underwent electroretinographic (Fig. I, overleaf, p. 410), ophthalmoscopic, and slit-lampexaminations to ensure that they were free from pathological disorders. Ophthalmoscopic and slit-lamp examinations were carried out on conscious dogs, the electroretinogram (ERG) was recorded under pentobarbital anaesthesia. The techniques and parameters of stimulation and recording have been described previously (Rosner and Legros, 1970).

The ERG was recorded during a period of dark-adaptation lasting $30 \mathrm{~min}$; then the eyes were dazzled for $90 \mathrm{sec}$. and the ERG was recorded during the following $5 \mathrm{~min}$. Stimulations (150 $\mu \mathrm{sec}$. 0.3 Joule) were successively red, blue, and white. We studied the electroretinogram on the one hand in a static manner (in this case the parameter used was the maximum amplitude of the $a$ and $b$ wave which was obtained during the 30 min. dark-adaptation) and, on the other hand, in a dynamic 
manner (comparison of the curves of dark-adaptation obtained by plotting the amplitude of the $a$ or $b$ wave against the time of adaptation).

At autopsy one eye of each dog was used for biochemical estimation and the other for histopathology.

\section{Results}

I SLIT-LAMP EXAMINATION

Controls and treated dogs were examined 2 and $4 \mathrm{mths}$ after the start of treatment and again $3 \mathrm{mths}$ after the cessation of treatment. No corneal deposits were observed in of any of the animals and no opacities capable of modifying the quantity of light received $\vec{\circ}$ on the retina were detected in the anterior regions of the lens.

\section{ELEGTRORETINOGRAPHIG STUDY}

The ERG was recorded in all animals Io wks and $4 \mathrm{mths}$ after the beginning of treatment then I, 3, and 5 months after interrupting medication. For each animal the response was taken as the average of the responses given by the right and left eyes. Before beginning treatment it was verified that there was no statistically reproducible difference in the ERG $\bigcirc$ of the different experimental groups.

\section{(I) Controls}

There was no statistically significant modification in the ERG during experimentation except after $4 \mathrm{mths}$ (Table I), when some changes appeared.

Table I Electroretinographic changes obtained in a scotopic environment in controls.

For each recording and stimulation the variations of $\mathrm{a}$ and $\mathrm{b}$ waves are expressed as a percentage of the initial value.

The values correspond to the mean of the changes in controls plus or minus the standard error.

\begin{tabular}{|c|c|c|c|c|c|c|}
\hline \multirow{4}{*}{$\begin{array}{l}\text { Stimulation } \\
\text { White }\end{array}$} & \multirow{4}{*}{$\begin{array}{l}\text { Wave } \\
\mathrm{a} \\
\mathrm{b}\end{array}$} & \multicolumn{5}{|c|}{ Time after start of experimentation (mths) } \\
\hline & & $2 \frac{1}{2}$ & 4 & 5 & 7 & 9 \\
\hline & & $+0.05 \pm 6.0$ & $+25 \cdot 1 \pm 7 \cdot 1^{*}$ & $-12.0 \pm 4.7 !$ & $-8 \cdot 9 \pm 11 \cdot 6$ & $-11 \cdot 2 \pm 12 \cdot 1$ \\
\hline & & $+4.7 \pm 2.8$ & $+8 \cdot 1 \pm 4 \cdot 8$ & $-1 \cdot 1 \pm 3 \cdot 5$ & $-4.9 \pm 6.8$ & $-1 \cdot 4 \pm 1 \cdot 1$ \\
\hline Red & b & $+9.3 \pm 5.3$ & $+21 \cdot 4 \pm 8 \cdot 1 t$ & $-2.5 \pm 5.8$ & $-6 \cdot 3 \pm 8 \cdot 1$ & $-11 \cdot 4 \pm 6 \cdot 6$ \\
\hline \multirow[t]{2}{*}{ Blue } & $\mathbf{a}$ & $+22.6 \pm 15.9$ & $+42 \cdot 3 \pm 12 \cdot 2^{*}$ & $-8.4 \pm 9.0$ & $-0.06 \pm 19.8$ & $-8.0 \pm 10.2$ \\
\hline & $\bar{b}$ & $+7 \cdot 7 \pm 4 \cdot 7$ & $+8 \cdot 5 \pm 7 \cdot 1$ & $+0.06 \pm 6.6$ & $-6.2 \pm 5.9$ & $-3 \cdot 7 \pm$ \\
\hline
\end{tabular}

The values obtained during experimentation are compared to those obtained before the beginning of experimentation with the 을 Student-Fisher test.

Degree of statistical reproducibility: $\quad \dagger 0.1 \leqslant P \& 0.05 \quad * P<0.01$

(2) Dogs treated with chlorpromazine

(a) Static study (Table II, opposite)

The amplitude of the $a$ and $b$ waves was diminished in both the treatment and the post- $\stackrel{\Phi}{\oplus}$ treatment periods. This decrease is statistically insignificant by comparison with the control 0 animals during the medication period and compared with the initial values in the same group for the post-medication period. This latter fact is due to the accentuation of the ERG amplitude decrease in the period free of medication. 
.

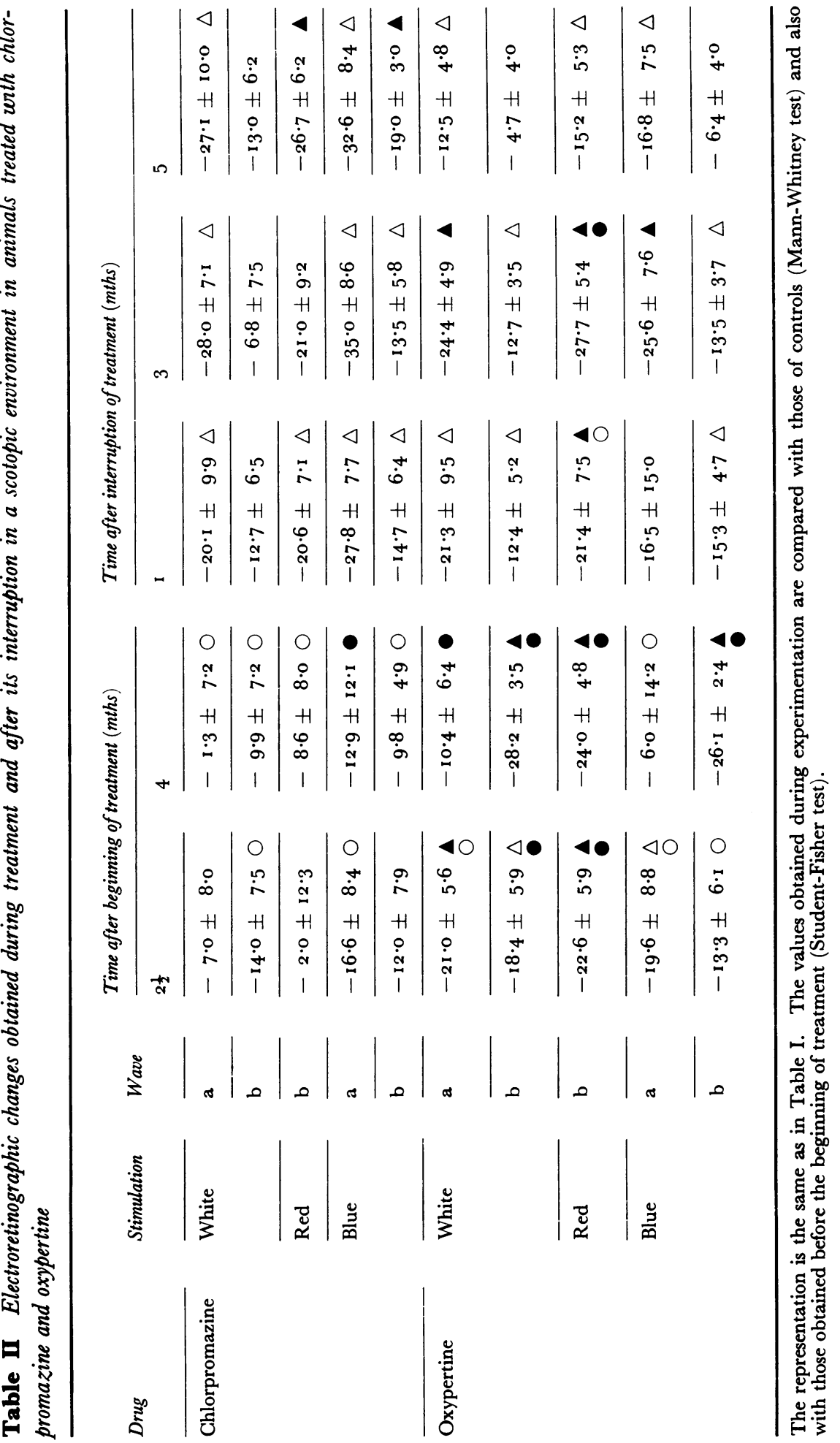




\section{(b) Dynamic study}

The curves of dark-adaptation obtained during the treatment or after its interruption $\frac{0}{3}$ were always below the initial level, but the difference is statistically significant only after $\stackrel{0}{.}$ the interruption of medication (Fig. 2, opposite). The curves of the dogs treated with $\overrightarrow{\vec{s}}$ chlorpromazine were always below those of the controls (Figs 3 and 4).
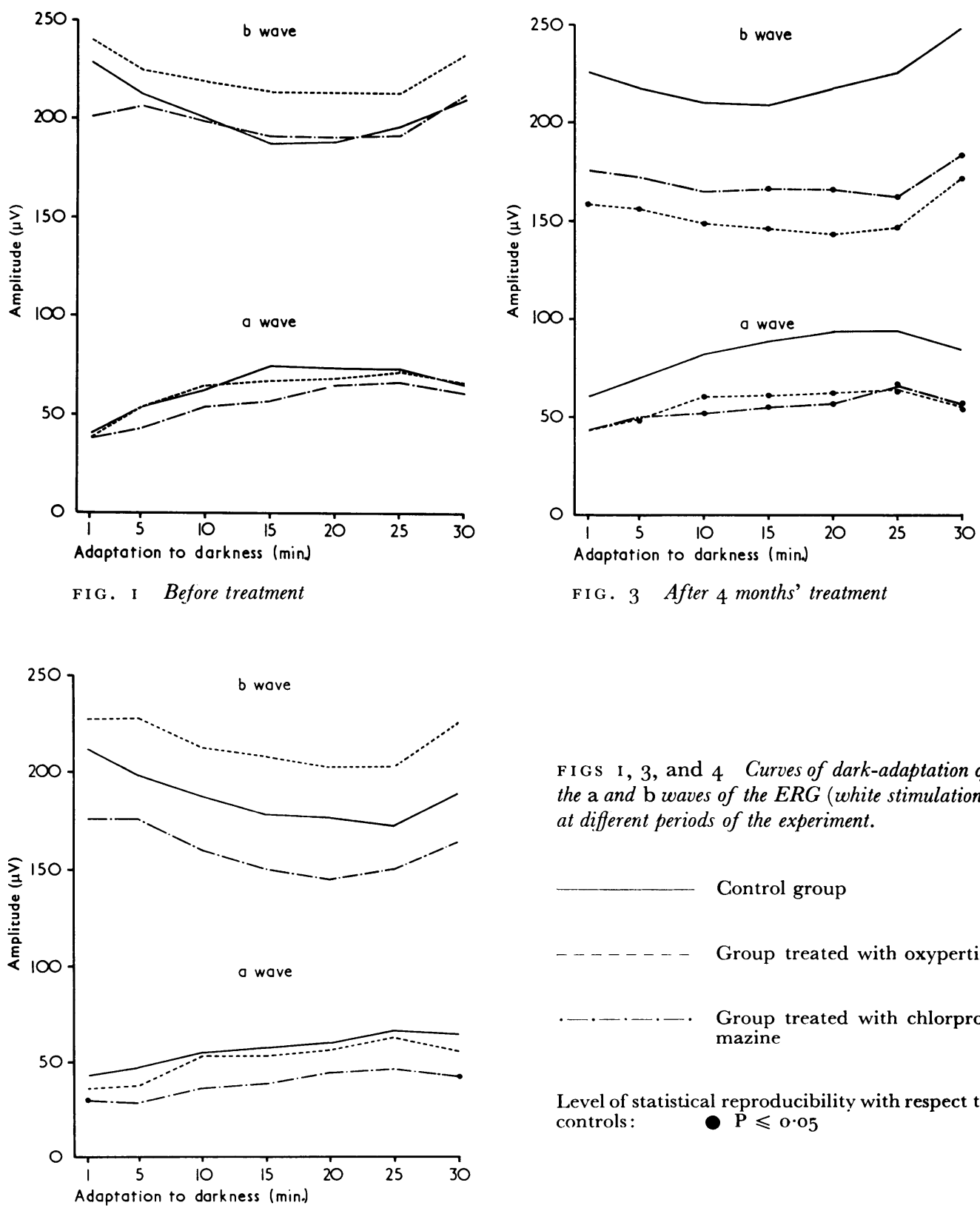

F IGS I, 3, and 4 Curves of dark-adaptation of 0 the $\mathrm{a}$ and $\mathrm{b}$ waves of the ERG (white stimulation) at different periods of the experiment.

\section{Control group}

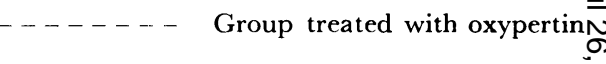

Group treated with chlorpro-N mazine

Level of statistical reproducibility with respect to controls :

- $\mathrm{P} \leqslant 0 \cdot 05$

FIG. 45 months after treatment 
(3) Dogs treated with oxypertine

(a) Static study (Table II)

After Io weeks of treatment there was a statistically significant decrease in the $a$ and $b$ waves. At the end of treatment, the diminution of the $b$ wave became more pronounced, whereas there was an improvement in the $a$ wave. After stopping the medication, there was a progressive return towards normal in the $b$ wave and after 5 months the difference from the initial level was no longer statistically significant except with the red stimulation. On the other hand, the $a$ wave became slightly smaller and the difference was statistically significant. The difference between treated animals and controls observed at the end of treatment disappeared after stopping medication.
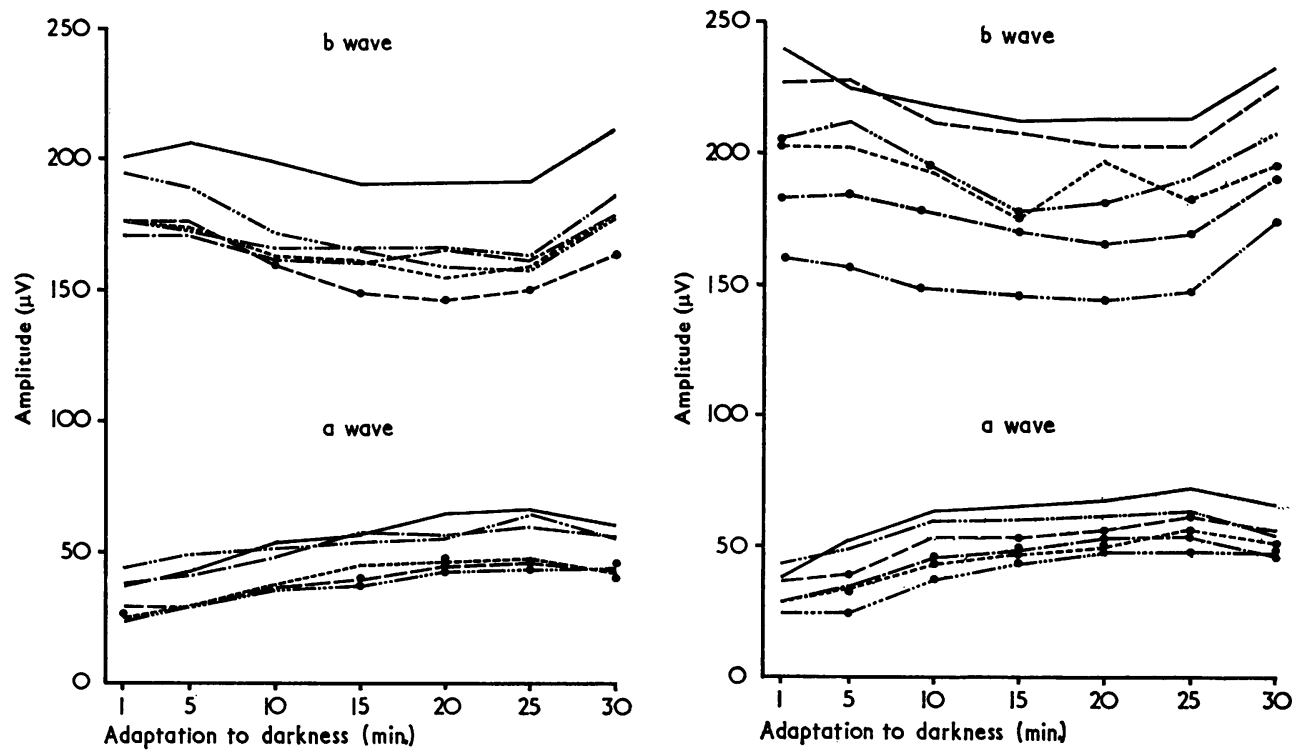

FIGS 2 and 5 Curves of dark-adaptation at different periods of the experiment in the group treated with chlorpromazine (Fig. 2) and in the groups treated with oxypertine (Fig. 5).

Level of statistical reproducibility with respect to initial value (before beginning treatment): $\quad P \leqslant 0.05$

\begin{tabular}{|c|c|c|c|}
\hline & Before treatment & ------- & I month after stopping treatment \\
\hline$-\cdot-$ - - - - & After 10 weeks' treatment & $-\cdots-\cdots-\cdots$ & 3 months after stopp \\
\hline$\cdots-\cdots$ & After 4 months' treatment & $-\longrightarrow-$ & fter stopp \\
\hline
\end{tabular}

\section{(b) Dynamic study}

The curves of dark-adaptation obtained during treatment were at a lower level than the premedication curve and the difference was statistically significant. After stopping the medication there was a progressive improvement which was total for blue and white stimulations (Fig. 5). The changes were more pronounced for the $b$ wave than for the $a$ wave. During the treatment period, the curves of dark-adaptation of the treated animals were below those of the controls and the difference was more often statistically significant. After stopping the treatment there was a progressive improvement and after 5 months they were at the level of, or slightly above, those of the controls (Figs 3 and 4 ). 


\section{OPHTHALMOSCOPIC EXAMINATIONS}

These were carried out just before or immediately after the electroretinographic recordings, and photographs of the fundi were taken; the examiner did not know to which group $\underline{\underline{3}}$ each dog belonged. With oxypertine, clear changes in the fundus were visible only after 4 months of treatment; there were decreases in brilliance of the tapetum lucidum, con- $\stackrel{5}{+}$ junctival secretions, and ocular irritation. After medication was stopped all the dogs $\frac{0}{0}$ progressively returned to normal. At the end of the treatment, no change was visible with chlorpromazine except in one dog in which there was a spreading of the green margin; $\vec{\otimes}$ a decrease in the tapetum lucidum brilliancy appeared after stopping the treatment in three out of the seven dogs and persisted in two of these three after 5 months. At this $\vec{\circ}$ time the green margin between the two tapeta in dogs medicated with chlorpromazine tended to be blue-green while in dogs medicated with oxypertine and in the controls it was emerald green.

\section{BIOCHEMICAL ESTIMATIONS}

The results are summarized in Table III. As estimations were made 5 months after $\vec{f}$ stopping medication the quantity of drug fixed in the eye was very small except in one $\operatorname{dog}$ o

Table III Biochemical estimation of the quantity of drug fixed in the eyes of dogs treated with oxypertine and chlorpromazine

\begin{tabular}{|c|c|c|}
\hline Medication & Dog no. & $\begin{array}{l}\text { Quantity fixed in } \\
\text { the eye }(\mu g . / g .)\end{array}$ \\
\hline \multirow[t]{2}{*}{ Control $\left(\mathrm{H}_{2} \mathrm{O}\right)$} & I 6 & $0 \cdot 0$ \\
\hline & 28 & $0 \cdot 0$ \\
\hline \multirow[t]{7}{*}{ Oxypertine } & I & $2 \cdot 0$ \\
\hline & 4 & $I \cdot 2$ \\
\hline & 5 & $I \cdot I$ \\
\hline & 9 & $\mathbf{I} \cdot 6$ \\
\hline & 20 & $\mathrm{I} \cdot 6$ \\
\hline & 25 & $\mathrm{I} \cdot 8$ \\
\hline & 30 & $2 \cdot 0$ \\
\hline \multirow[t]{8}{*}{ Chlorpromazine } & 3 & $\mathrm{I} \cdot 6$ \\
\hline & I I & $0 \cdot 9$ \\
\hline & I 5 & $0 \cdot 0$ \\
\hline & 17 & $\mathrm{I} \cdot 3$ \\
\hline & 22 & $0 \cdot 0$ \\
\hline & 27 & $0 \cdot 0$ \\
\hline & 24 & I $3 \cdot 3$ \\
\hline & $7^{*}$ & $76 \cdot 8$ \\
\hline
\end{tabular}

*This dog died after I I weeks of treatment. The eyes were removed immediately after death. For chlorpromazine estimation the method was spectrophotometry of total phenothiazines; the results are expressed in total phenothiazines in the form of $\mathbb{D}$ chlorpromazine equivalent $(\mathrm{HCl})$ which gives the $\stackrel{?}{+}$ same optical density.

For oxypertine estimation the method was fluoro- $\frac{0}{0}$ metry of total extract. Results are expressed in total $\vec{\Phi}$

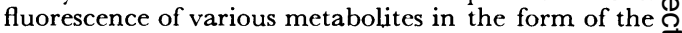
oxypertine equivalent which has the same fluorescence.

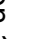


treated with chlorpromazine (No. 24). The quantity was far greater in the dog which was still receiving chlorpromazine treatment at the time of its accidental death (No. 7).

\section{HISTOPATHOLOGY}

The eyes of controls and of dogs treated with oxypertine were completely normal on histopathological examination.

In the groups medicated with chlorpromazine, only seven of the original eight dogs could be examined; in the one which died accidentally the eyes showed post mortem autolysis. Three of the seven dogs medicated with chlorpromazine exhibited peripheral or central intraretinal cystic formations, some of which were bordered by a lympho-histiocytic infiltration spreading along a dilated vessel (Figs 6 and 7). One showed a marked diffuse congestion of the retinal vascular system.

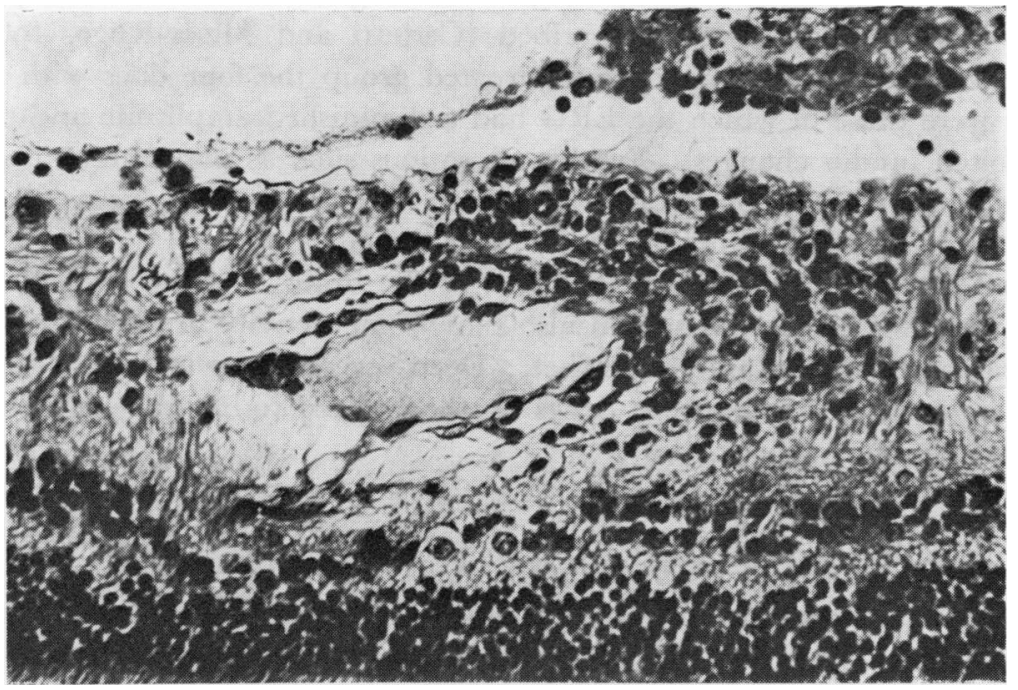

F I G. 6 Dog No. I I treated with chlorpromazine. Trichrome stain. $\quad \times 35^{\circ}$

Retinal granuloma

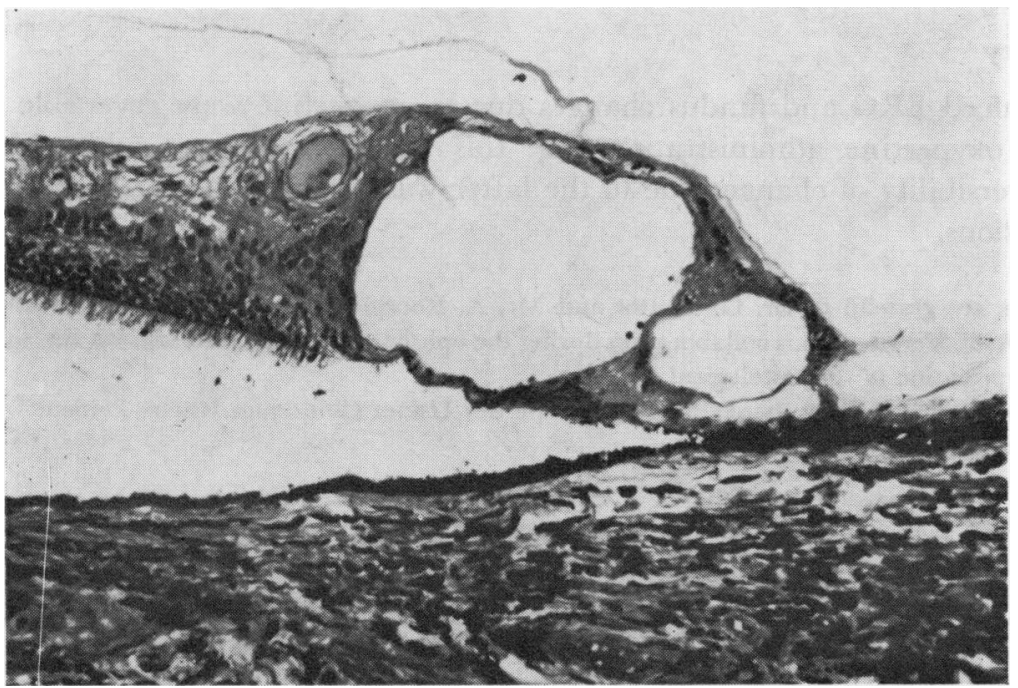

F I G. 7 Dog No. I I treated with chlorpromazine. Trichrome stain. $\times 175$ 


\section{Discussion}

The ratio of the dose levels of oxypertine and chlorpromazine ( $1: 2)$ is very near to the usual therapeutic ratio as well as to that determining an equivalent pharmacological activity $(\mathrm{I}: 2 \cdot 5)$. Both oxypertine and chlorpromazine administered to dogs at high sub-toxic dose levels are able to induce ocular modifications. No drug or only an extremely small quantity was found in the eye 5 months after stopping medication and this despite the well-described affinity of chlorpromazine for ocular tissues (Mathalone, I967; Potts, I962; Potts, 1964; Reinert and Rutty, I969). These results are quite different from those obtained with quinolines which are eliminated far more slowly from melanincontaining tissues (McChesney, Banks, and Sullivan, i965). No corneal or lens pigmentation was found in dogs, whereas a deposit of yellowish or brown pigment in the cornea and pigmentation (capsular and subcapsular) of the lens have been described in man during chlorpromazine treatment (Greiner and Berry, I964; Mathalone, I967; Petrohelos and Tricoulis, I969; Siddall, I965). Histological alterations after phenothiazine treatment have previously been described (Cerletti and Meier-Ruge, I968) and our results show that in the chlorpromazine-treated group the four dogs with retinal histopathology were those in which the ERG had a diminished amplitude and three of these dogs exhibited fundus changes. Fundus alterations such as pigmentation, pallor of the optic discs, and attenuation of vessels have been reported in man (Boet, 1969; Goar and Fletcher, I957; Petrohelos and Tricoulis, I969; Siddall, 1965).

Since ontogenetically the retina is a part of the brain, it is not surprising that drugs acting on the central nervous system also show some activity at the retinal level, which may appear as an undesirable side-effect. Deep reversible or irreversible alterations in the ERG induced by psychotropic drugs on the isolated retina have been described by Lutzow and Hommer ( 1969 ).

All potent drugs have their associated side-effects; their presence is obviously important but just as significant is their reversibility after stopping medication. Our data on these two neuroleptics indicate a reversibility for oxypertine-induced ocular changes, whereas those induced by chlorpromazine are not reversible. This situation should be correlated with the fact that no ocular side-effects have been reported after oxypertine treatment in humans.

\section{Summary}

Drug-induced ERG and fundus changes due to oxypertine were reversible in dogs after stopping oxypertine administration, but this was not the case with chlorpromazine. The irreversibility of changes due to the latter was associated with the presence of histological lesions.

The authors are grateful to Dr. G. Mottot and Mr. A. Rouquès for their help. They are also greatly indebted to Dr. P. Vergne for his collaboration during the ophthalmoscopic examinations and to Dr. P. Dusserre for his interpretation of the histological slides.

The authors express their thanks to the "Société des Usines Chimiques Rhône-Poulenc" who kindly put the chlorpromazine at their disposal.

\section{References}

вOET, D. J. (1969) Ophthalmologica (Basel), 158, Suppl., p. 574

CERIETti, A., and MeIER-RUge, W. (I968) In "Proceedings of the European Society for the Study of

Drug Toxicity", vol. 9, p. I 70 
FRANCESGhetTI, A., FRANçOIs, J., and BABEL, J. (1963) "Les hérédo-dégénérescences chorio-rétiniennes". Masson, Paris

GOAR, E. L., and FLETCHer, м. c. (1957) Amer. F. Ophthal., 44, 603

GreINER, A. C., and BerRy, K. (1964) Canad. med. Ass. F., 90, 663

GRÜTZNER, P. (1969) Ophthalmologica (Basel), 158, Suppl., p. 592

HENKES, H. E. (1967) Trans. ophthal. Soc. U.K., 87, 285

LEINFELDER, P. J., and BURIAN, H. м. (1964) Invest. Ophthal., 3, 466

LÜTzow, A. VON, and HOMMER, K. (1969) Ophthalmologica (Basel), 158, Suppl., p. 647

McCheSNEy, E. W., Banks, w. F., and sullivan, D. J. (1965) Toxicol. appl. Pharmacol., 7, 627

McDonald, G. J., SNell, R. S., and LeRner, A. B. (1967) J. invest. Derm., 49, 39

MATHALONE, M. B. R. (1967) Brit. F. Ophthal., 51, 86

PETROHELOS, M. A., and TRICOULIS, D. (I968) Ophthalmologica (Basel), 158, p. 469

Pоттs, А. м. (1962) Invest. Ophthal., 1, 522 (1964) Ibid., 3, 399

REINERT, H., and RUTTY, D. A. (1969) Toxicol. appl. Pharmacol., 14, 635

rosner, I., and Legros, J. (1970) Arch. Ophtal. (Paris), 30, 865

SIDDAll, J. R. (1965) Arch. Ophthal. (Chicago), 74, 460

SMITH, A. A., GAVITT, J. A., and KARMIN, M. (I966) Ibid., 75, 99

VERREY, F. (1956) Ophthalmologica (Basel), 131, 296

WAGNER, P. (1956) Klin. Mbl. Augenheilk., 129, 772

weInstock, м., and scotT, J. D. (1967) Exp. Eye Res., 6, 368 